\title{
EXPERIMENTAL AND NUMERICAL INVESTIGATION OF CONVECTION HEAT TRANSFER IN AN ENCLOSURE WITH A VERTICAL HEATED BLOCK AND BAFFLES
}

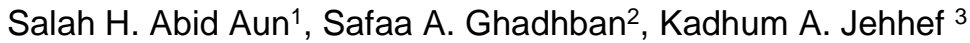

\begin{abstract}
In this study, the natural and forced convection heat transfer in an enclosure with vertical heated block and baffles are experimentally and numerically investigated. The enclosure walls are kept as adiabatic, and the heating block contains extended baffles and receives heat flux. The effect of heat flux, Reynolds number and baffle configuration on the heat transfer characteristics and flow behaviour inside the enclosure is examined. The configuration parameter for natural and forced convection involves three heating block models, namely, block without baffle (plain), block with baffles and block with partially cut baffles. The widths of baffles are $2.5,5$ and $10 \mathrm{~cm}$ for the block with baffle case, and the width of partially cut baffle is $5 \mathrm{~cm}$. The heat flux (q) ranges from $240 \mathrm{w} / \mathrm{m}^{2}$ to 1425 $\mathrm{w} / \mathrm{m}^{2}$ for all the models. The Reynolds number (Re) ranges from 5650 to 15950 for forced convection heat transfer. In the numerical part, a finite volume method (via Ansys Fluent) is used to solve the governing equations. Result shows that the increase in baffle width has no remarkable effect on the heat transfer, and the partially cut baffles provide an enhancement of approximately 30\% compared with the plain heating block. The baffle cases have an evident effect in reducing the block surface temperature by approximately $11 \%$ compared with the plain case at $\operatorname{Re}=0$ and $q=240$ $\mathrm{w} / \mathrm{m}^{2}$. Empirical correlations for the block with baffles are obtained for each heat flux to predict the average Nusselt number.
\end{abstract}

Keywords: Heat Transfer Enhancement, Nusselt Number, Enclosure, Heating Block, Baffles

\section{INTRODUCTION}

Modern technologies seek new and efficient heat transfer systems to ensure maximum cooling effectiveness. Therefore, studying the heat transfer characteristics of natural, forced and mixed convection is necessary. Many engineering applications, such as heat exchangers, electronic system cooling, air conditioning, nuclear reactor cooling, industrial furnaces and solar energy storage, require deep investigation for convective heat transfer system. Different methods, such as Nano fluids, functionally graded materials and extrude baffles, are widely used to enhance heat transfer which is useful to keep the temperature-dependent material properties at designed ranges, increase efficiency of cooling units or reduce pump power of heat exchanger [1-5]. Many experimental and theoretical investigations are performed to study the heat transfer performance in enclosures with baffles.

Laguerre et al. [6] presented an experimental model based on the refrigeration system, where the closed cavity contains warm and cold vertical walls with insulated horizontal walls. They found that heat transfer is enhanced near the cold wall with the presence of hollow spherical blocks that fill the refrigerator. Himsar et al. [7] numerically studied two insulated baffles attached to the horizontal adiabatic wall of a heated square cavity using the finite volume method. The result shows that the Nusselt number $(\mathrm{Nu})$ increases as a function of Rayleigh number, decreases with baffle length, and is strongly dependent on baffle position. Nabeel and Selah [8] numerically investigated the laminar forced convection heat transfer and fluid flow in horizontal channel. Different baffle geometries, including flat plate, square and triangle are considered. The result shows that the geometry and location of the baffle play a major role in increasing the value of $\mathrm{Nu}$. The laminar flow and heat transfer performance in a square channel with $30^{\circ}$ angled baffles at different

This paper was recommended for publication in revised form by Regional Editor Mohammad Ghalambaz

${ }^{1}$ Middle Technical University, Institute of Technology- Baghdad, Iraq

${ }^{2}$ Middle Technical University, Electrical Engineering Technical College- Baghdad, Iraq

${ }^{3}$ Middle Technical University, Institute of Technology-Baghdad, Iraq

*E-mail address: dr.salah_haji102@mtu.edu.iq, safaaabid@mtu.edu.iq, kadhumaudaa@gmail.com

Orcid id: 0000-0002-4813-306X, 0000-0002-6305-8096, 0000-0002-4859-6048

Manuscript Received 31 May 2020, Accepted 25 September 2020 
pitch ratios (PRs) were numerically explored by Withada et al. [9]. They found that optimum thermal performance enhancement is obtained at $\mathrm{PR}=2.5$.

Ahmed et al. [10] conducted a numerical analysis for square cavity containing heated rectangular blocks adjacent to upper wall. Different variables, such as the height of the blocks, Reynolds and Rayleigh numbers (Ra), were studied. The result demonstrates that the Nusselt number increases with block height. Asif et al. [11] illustrated the influence of Reynolds and Richardson numbers (Ri) on the Nusselt number and heating efficiency in an enclosure with baffles placed at the side walls. They found that maximum heat transfer is achieved with high value of $\mathrm{Re}$ and $\mathrm{Ri}$ numbers.

Ahammed et al. [12] numerically explored the mixed convection flow in ventilated cavity. Heat was subjected to the bottom wall of the cavity, and the other walls were kept insulated. The researchers achieved effective heat transfer at low thermal conductivity ratio of the solid/fluid. Rague et al. [13] numerically investigated the natural convection in a square cavity. The enclosure consisted of hot bottom and adiabatic upper walls and a vertical wall maintained at a cold temperature. They found that $\mathrm{Nu}$ increases as a function of Ra. Armando et al. [14] conducted numerical and experimental studies on vertical cavity, where its vertical wall receives heat flux, the opposite wall is kept at a constant temperature, and its remaining walls are assumed to be adiabatic. The change in wall emissivity from 0.03 to 0.95 increases the heat transfer coefficient from $119.9 \%$ to $159.9 \%$. Barka et al. [15] numerically studied a T-shaped cavity containing two heated blocks using the finite volume method, focusing on the effect of inclination angle, (Re) and (Ra) on $(\mathrm{Nu})$ and flow field behaviour. They found that the heat transfer decreases by increasing the inclination angle. Louhibi et al. [16] conducted a numerical analysis for rectangular channel containing inclined baffles. A better heat transfer enhancement is achieved with the increase in baffle inclination.

Yasin and Filiz [17] numerically explored the effect of an adiabatic fin mounted with a vertical wall on the natural convection inside a square enclosure. They reported that natural convection and flow field are significantly affected by (Ra) and fin thickness. Carozza [18] developed a numerical model to simulate air flow through a heat exchanger inside the engine vane of a helicopter. The best place of heat exchanger is found to be near the lower exit on the rear to increase the air flow rate. Kumar et al. [19] experimentally tested a V-pattern baffle inside a rectangular channel to understand the influence of attack angle, baffle height and PR on the Nusselt number and friction factor. The V-pattern baffle provides better improvement in heat transfer compared with different baffle shapes. Amnart and Withada [20] numerically studied the influence of using a square channel with discrete combined V-baffle and Vorifice on the heat transfer improvement. They summarised that the channel with discrete combined baffle improves the heat transfer rate by approximately 2.8-6 times higher than the smooth channel.

Ahmed et al. [21] numerically examined the baffles in exhaust mufflers to improve their transmission loss. The results show that the temperature of outlet gases decreases by $15 \%$ with the change in baffle cut ratio from $75 \%$ to $25 \%$. Amghar et al. [22] reported that spacing between the baffles improves the heat transfer by forced convection during the turbulent flow with transverse baffles inside a horizontal channel. Eva et al. [23] studied combined conduction, convection and radiation heat transfer in a closed horizontal airy cavity, where its thickness and inner surface emissivity are tested with constant heat flux. They found that the increase in cavity thickness decreases the heat flux. Adis [24] numerically investigated the heat transfer inside a cavity with heated base attached to fins to evaluate the effects of configuration parameters of the fins on the heat transfer of laminar flow. The heat transfer is enhanced by around $120 \%$ using short, thin fins compared with that of cavity without fins. Sannad et al. [25] numerically analysed the heating block position inside a cavity filled with nano - fluids. The results illustrate that the volume fraction of nano-fluid and Rayleigh number ( $\mathrm{Ra})$ improve the heat transfer.

The present work focuses on enhancing heat transfer by using different heating blocks containing baffles with heater in one block. Partially cut baffles are used, and natural and forced convection heat transfer are investigated at the same operating conditions (inlet temperature, inlet pressure, heat flux) with turbulent flow. The mixed convection heat transfer in the presence of turbulent flow with the variation of Reynolds number and heat flux is evaluated. Experimental and numerical models are considered to better understand the heat transfer enhancement and fluid flow behaviour around the blocks and inside the enclosure. During the enhancement of heat transfer, many parameters, such as cost, occupied space and applicability, should be considered. The enhancement using forced convection is at the expense of cost or occupied space because of the use of fans. The design of baffles in natural convection is sometimes 
limited in applications. Consequently, forced convection is preferred in cooling this application without using the baffles. The above and similar reasons make the present work to study the natural and forced convection at the same conditions to obtain the comparison between them for all the tested models. The novelty of this work is investigation the effect of using partially cut baffles, attached to the heated block, on heat transfer characteristics. Moreover, numerical and experimental methods can examine different convective systems under the same assumption and condition.

\section{EXPERIMENTAL DETAILS}

An experimental test rig shown in Figures 1-A and 1-B was built to study the heat transfer performance inside the enclosure with baffles under varying heat flux and Reynolds number for different configurations.

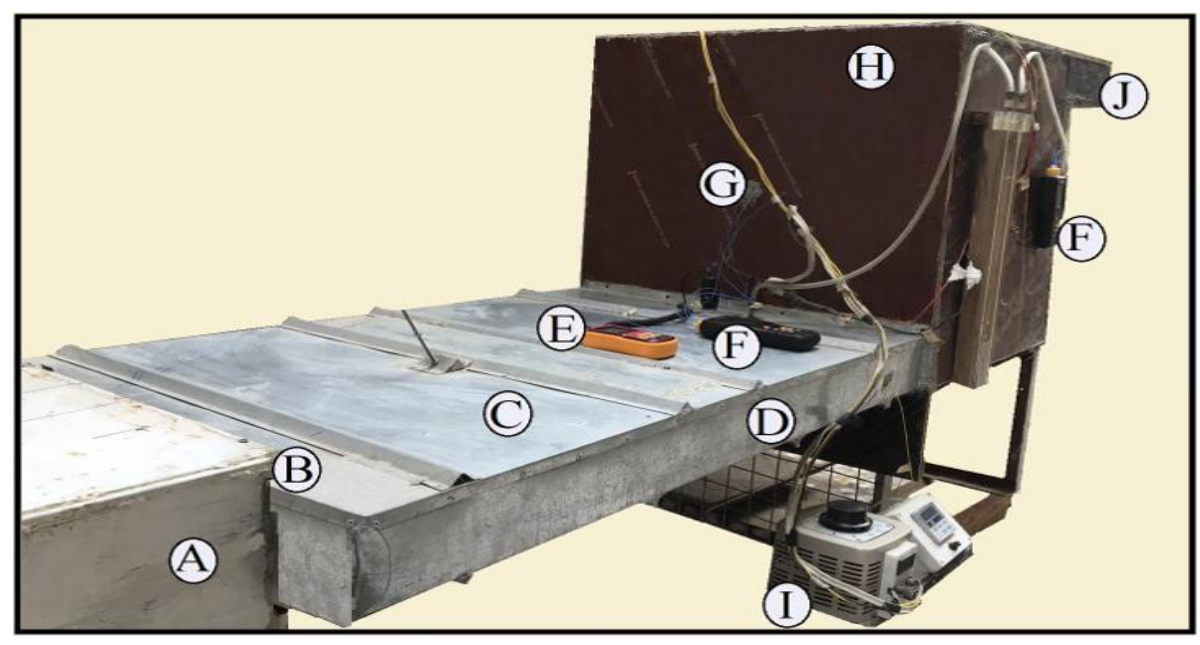

Figure 1-a. Experimental test rig

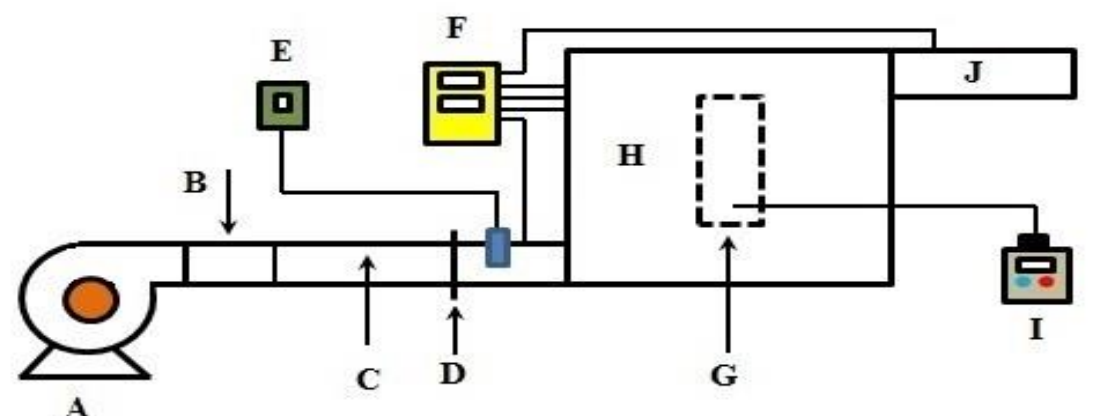
A: Fan
B: Diffuser section
C: Air inlet duct
D: Stainless steel mesh
E: Anemometer

\section{F: Thermocouple temperature indicator \\ G: Heating block \\ H: Enclosure \\ I : Electrical controller \\ J: Outlet duct}

Figure 1-b. The schematic of experimental test rig setup

The test rig contains enclosure, fan, air inlet duct, exhaust duct and measurement devices. The enclosure consists of the main part of the testing rig, with a total size of $80 \mathrm{~cm} \times 80 \mathrm{~cm} \times 60 \mathrm{~cm}$, as shown in Figure (2). The 
enclosure is designed to be suitable for conducting different types of tests involving laminar and turbulent flow as well as heat transfer by forced and free convection. The enclosure walls are made from wood to prevent heat loss to the environment. The low thermal conductivity of the wood provides better insulation. Therefore, the walls are assumed to be adiabatic walls, as presented in Figure 2. The heating block is placed in the middle of enclosure and connected with front and rear sides for fixing. It is made of galvanised iron with a total size of $80 \mathrm{~cm} \times 60 \mathrm{~cm} \times 10 \mathrm{~cm}$. The heating block is designed corresponding with enclosure such the flow field can be studied clearly. Three electrical heaters (600 $\mathrm{W})$ are used inside the block. The supplied heat power varies from $200 \mathrm{~W}$ to $1200 \mathrm{~W}$ with an electrical controller (Variac).
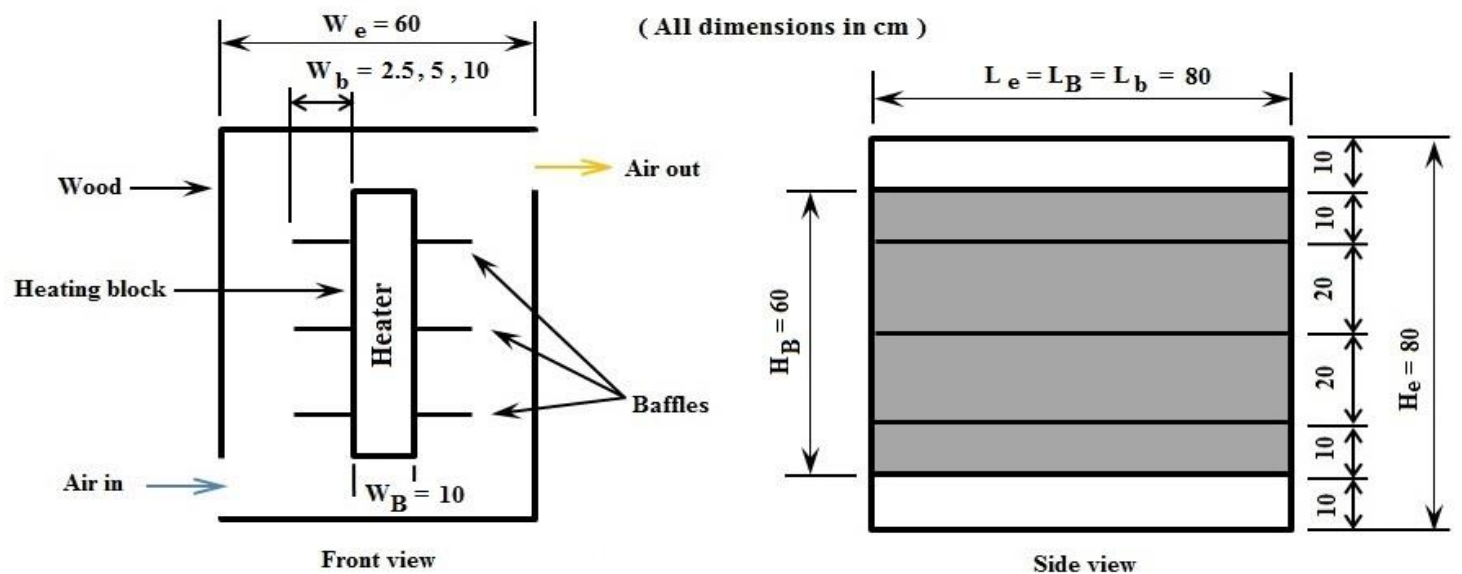

Figure 2. Schematic diagram of enclosure

The baffles are fixed at the heating block and have the same block material. The length of the baffles is 80 $\mathrm{cm}$, and their width ranges from $2.5 \mathrm{~cm}$ to $10 \mathrm{~cm}$. To cool the heating block, air is supplied by the fan because the air flows inside the air duct, enters the enclosure through the bottom side, flows inside the enclosure, and leaves from the top side towards the outlet duct. The design of flow path from bottom side to top side is more suitable for natural convection as well as forced convection tests. The cross-section area dimensions of ducts are $80 \mathrm{~cm} \times 10 \mathrm{~cm}$, and the hydraulic diameter ( $\mathrm{Dh})$ is $17.7 \mathrm{~cm}$. The inlet duct contains a divergence section and stainless-steel mesh to ensure stable and uniform air flow in the enclosure entrance [26], as shown in Figure 3.

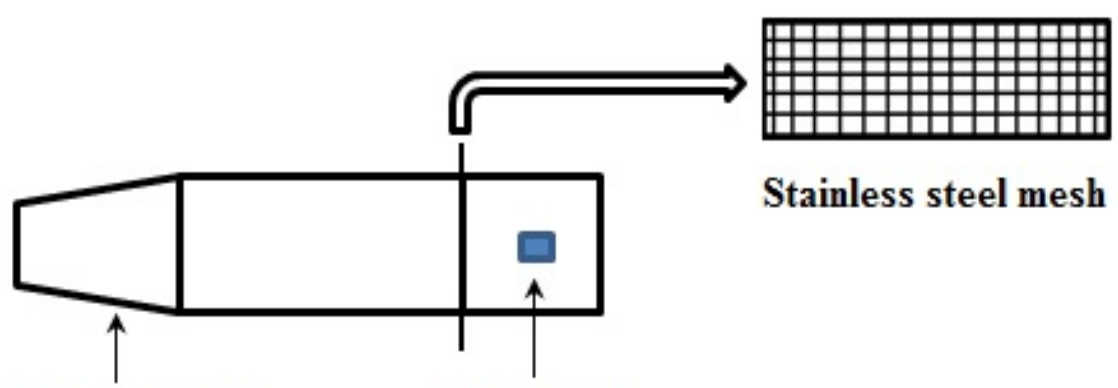

Diffuser section

Anemometer

Figure 3. Top view of air inlet duct 
Fan speed control and gate adjustment are used to calculated as the air velocity, and a digital anemometer (GM8901) is used to measure the air velocity. Fourteen type k thermocouples are located at the test rig. Eight of them are used to measure the temperatures of the heating block surface, four thermocouples are immersed at the locations around the heating block, and two thermocouples are used to measure the temperatures of inlet and outlet air. All thermocouples and readers are calibrated with thermometer at the temperatures of ice melting point, water boiling point and midpoint between them [27]. The maximum error ranges between $0.8{ }^{\circ} \mathrm{C}-1.2{ }^{\circ} \mathrm{C}$. According to the methodology of [28], the accuracy of measurement is predetermined, and the uncertainty of Nusselt number is set $( \pm 3.27 \%)$.

\section{TEST MODELS AND CONFIGURATION}

As shown in Figure 4, five heating block models, including plain baffles with width $\left(\mathrm{W}_{\mathrm{b}}=2.5,5,10 \mathrm{~cm}\right)$ and partially cut baffles with triangle shape are experimentally tested. All the tests are conducted at steady state condition and under atmospheric pressure. The Reynolds numbers range from 0-16950 in accordance with the airflow velocity at the entrance, with ranges at $0,0.5,1,1.5 \mathrm{~m} / \mathrm{s}$ ). The configurations of test models and the studied parameters are shown in Table (1) in detail.

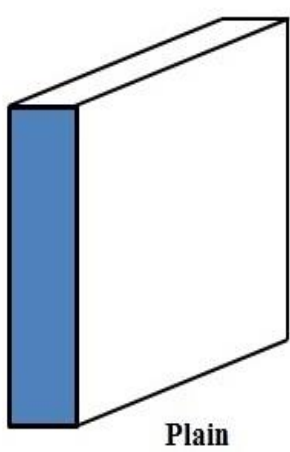

Plain

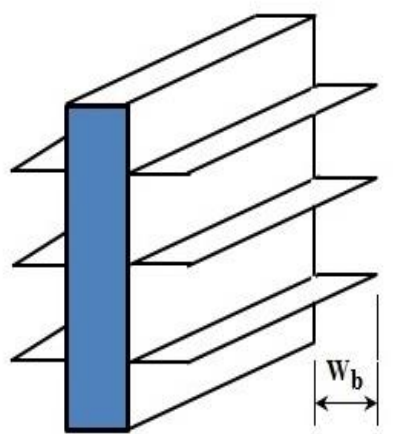

With baffles $\left(\mathrm{W}_{\mathrm{b}}=2.5,5,10 \mathrm{~cm}\right)$

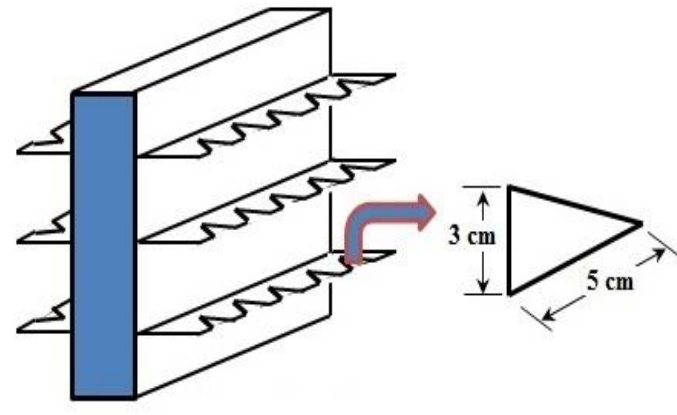

With cutting baffles

Figure 4. Heating block configurations

Table 1. Test models configuration and parameters

\begin{tabular}{|c|c|c|c|}
\hline & Plain & With baffles & Cutting baffles \\
\hline $\mathrm{L}_{\mathrm{B}}(\mathrm{cm})$ & \multicolumn{3}{|c|}{80} \\
\hline $\mathrm{H}_{\mathrm{B}}(\mathrm{cm})$ & \multicolumn{3}{|c|}{60} \\
\hline $\mathrm{W}_{\mathrm{B}}(\mathrm{cm})$ & \multicolumn{3}{|c|}{10} \\
\hline $\mathrm{W}_{\mathrm{b}}(\mathrm{cm})$ & 0 & $2.5-5-10$ & 5 \\
\hline $\mathrm{L}_{\mathrm{b}}(\mathrm{cm})$ & 0 & 80 & 80 \\
\hline $\mathrm{Re}$ & \multicolumn{3}{|c|}{$(0-5650-11300-16950)$} \\
\hline $\mathrm{q}\left(\mathrm{w} / \mathrm{m}^{2}\right)$ & \multicolumn{3}{|c|}{$(240-475-715-950-1190-1425)$} \\
\hline
\end{tabular}


Journal of Thermal Engineering, Research Article, Vol. 7, No. 3, pp. 367-386, March, 2021

\section{MATHEMATICAL PROCEDURES \\ HEAT TRANSFER CALCULATION}

A data acquisitor of thermocouples is used to calculate the heat transfer coefficient and Nusselt number. The measured properties are the temperatures of wall block, inlet and outlet and the air flow inside the cavity. The acquired data are recorded at steady state under the same inlet temperature.

The experimental value of average heat transfer coefficient is given by the following mathematical relationship [14].

$$
h=\frac{I V-Q_{\text {loss }}}{A\left(T_{w_{a}}-T_{\infty_{a}}\right)}
$$

Where (I) is the electric current and (V) is the voltage.

Where $\left(\mathrm{Tw}_{\mathrm{a}}\right)$ and $\left(\mathrm{T}_{\infty}\right)$ are the average temperatures of heated block surface and flow inside the cavity respectively.

$$
T w_{a}=\frac{\sum T_{w}}{N_{w}} \quad, \quad T_{\infty_{a}}=\frac{\sum T_{\infty}}{N_{\infty}}
$$

The average Nusselt number $\left(\mathrm{Nu}_{\mathrm{a}}\right)$ can be determined by using the convective heat transfer coefficient, [29].

$$
N u_{a}=\frac{h D h}{K_{\text {air }}} \quad, \quad D h=\frac{4 A}{P}
$$

The Reynolds number at the entrance of enclosure is given by:

$$
R e=\frac{\rho U D h}{\mu}
$$

The Richardson number equation is given by:

$$
R i=\frac{G r}{R e^{2}}
$$

\section{NUMERICAL MODEL}

In the numerical part, the commercial Ansys Fluent software is used to build the numerical model and to illustrate the thermal and fluid flow fields inside the cavity.

The enclosure model is presented in Figure 2. Constant fluid properties are considered, except density variation, which is treated in accordance with Boussinesq law. The present airflow is assumed as incompressible, 2D, steady and turbulent, [30]. The radiation model for the enclosure surfaces are assumed to be grey and diffuse in emission/reflection. The viscous flow and heat transfer inside the enclosure are described in terms of the $2 \mathrm{D}$ NavierStokes and energy equations, respectively.

Continuity equation [31]:

$$
\nabla .(\rho U)=0
$$

Momentum equation [31]:

$$
\nabla \cdot(\rho U U)=-\nabla P+\nabla\left(\tau+\tau^{T}\right)
$$


Journal of Thermal Engineering, Research Article, Vol. 7, No. 3, pp. 367-386, March, 2021

Energy equation [31]:

$$
\nabla \cdot\left(\rho c_{p} \bar{T} \bar{U}\right)=\nabla \cdot(k(\nabla T))-\nabla\left(\overline{U^{\prime} T^{\prime}}\right)
$$

The standard $k-\varepsilon$ model was employed according to Launder and Spalding [30]:

$$
\begin{gathered}
\nabla \cdot(\rho k U)=\nabla \cdot\left[\left(\mu+\frac{\mu_{t}}{\sigma_{k}}\right)(\nabla k)\right]+G_{k}-\rho \varepsilon \\
\nabla .(\rho \varepsilon U)=\nabla \cdot\left[\left(\mu+\frac{\mu_{t}}{\sigma_{\varepsilon}}\right)(\nabla \varepsilon)\right]+C_{1 \varepsilon} \frac{\varepsilon}{k} G_{k}-C_{2 \varepsilon} \rho \frac{\varepsilon^{2}}{k}
\end{gathered}
$$

The two terms $\mathrm{G}_{\mathrm{k}}$ and $\mu \mathrm{t}$ appearing above correspond to the shear and buoyancy rates of the turbulent kinetic energy respectively and are given by [32].

$$
\begin{aligned}
G_{k} & =-\rho \overline{u_{\imath}^{\prime} u_{\jmath}^{\prime}}(\nabla U) \\
\mu_{t} & =\rho C_{\mu} \frac{k^{2}}{\varepsilon}
\end{aligned}
$$

Table 2. Constants used in k-E turbulence model

\begin{tabular}{|l|l|l|l|}
\hline $\mathrm{C}_{\mu}$ & 0.09 & $\sigma_{\mathrm{T}}$ & 1.0 \\
\hline $\mathrm{C}_{1 \varepsilon}$ & 1.44 & $\sigma_{\mathrm{k}}$ & 1.0 \\
\hline $\mathrm{C}_{2 \varepsilon}$ & 1.92 & $\sigma_{\varepsilon}$ & 1.3 \\
\hline
\end{tabular}

The values for $\mathrm{k}$ and $\varepsilon$ next to the walls are calculated using the wall functions [32]:

$$
\begin{gathered}
k=\frac{u_{t}^{2}}{\sqrt{C_{\mu}}} \\
\varepsilon=\frac{u_{t}^{4}}{0.41 v y^{+}}
\end{gathered}
$$

The model boundary conditions are presented in Figure 5 as shown below:

At the inlet:

$$
U=u_{\text {in }} \quad, \quad V=0 \quad, \quad T=T_{\text {in }}
$$

At the outlet:

$$
\mathrm{P}=\mathrm{P}_{\mathrm{atm}} \quad, \quad \frac{\partial \emptyset}{\partial \mathrm{x}}=0
$$

At the insulated walls:

$$
U=V=0 \quad, \quad q=0
$$

At the heated block walls:

$$
U=V=0 \quad, \quad q=q^{\prime \prime}
$$




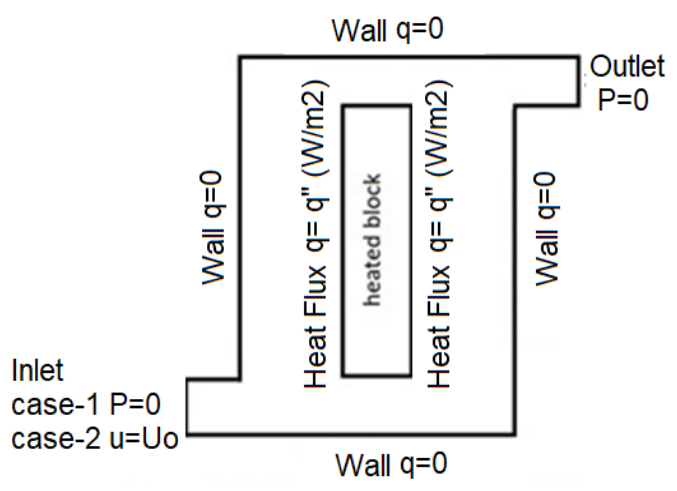

Figure 5. The boundary conditions of present study.

The described fluid flow and heat transfer system are discretised using the finite volume method with centred discretisation scheme. The coupling pressure-velocity is ensured using the SIMPLER algorithm [33], where the solution considers the conjugated gradient method. The optimal mesh size for the system is $500 \times 250$ to allow a better compromise (precision/calculation time). The average Nusselt number along the block is defined by [34]

$$
\begin{gathered}
\mathrm{Nu}=2+\int_{0}^{\mathrm{H}}\left[\left.\frac{\partial \theta}{\partial \mathrm{X}}\right|_{(\mathrm{X}=1-\mathrm{H} / 2, \mathrm{Y})}+\mathrm{Nr} \emptyset_{\mathrm{r}}(\mathrm{X}=1-\mathrm{H} / 2, \mathrm{Y})\right] \mathrm{dY} \\
+\int_{1-\mathrm{H} / 2}^{1+\mathrm{H} / 2}\left[-\left.\frac{\partial \theta}{\partial \mathrm{Y}}\right|_{(\mathrm{X}=1-\mathrm{H} / 2, \mathrm{Y})}+\mathrm{Nr} \emptyset_{\mathrm{r}}(\mathrm{X}, \mathrm{Y}=\mathrm{H})\right] \mathrm{dH}
\end{gathered}
$$

\section{GRID GENERATION AND NUMERICAL SOLUTION}

The finite volume method is used to generate the grids for the entire geometrical domain. Gambit 2.3.16 software is utilised to simplify the construction geometry and construct the mesh. Figure 6 shows the mesh section of the enclosure. The 2D mesh of the computational domain is exported to Ansys Fluent 18.0. The inlet and outlet pressure boundary conditions are considered with the SIMPLE algorithm. The system model adopts residual below $10^{-7}$ for the continuity, momentum and energy equations for each simulation evaluated during the course. The under relaxation factors for pressure and momentum are modified to 0.70 and 0.30 , respectively, but the density and energy are kept at the default values to improve the convergence rate of the models. In these numerical simulations, the convergence criteria for temperature, pressure and velocity are [35]

$$
\text { Error }=\frac{\sum_{k=1}^{l} \sum_{i=1}^{m} \sum_{j=1}^{n}\left|\xi_{i, j, k}^{t+1}-\xi_{i, j, k}^{t}\right|}{\sum_{k=1}^{l} \sum_{i=1}^{m} \sum_{j=1}^{n}\left|\xi_{i, j, k}^{t+1}\right|} \leq 10^{-7}
$$

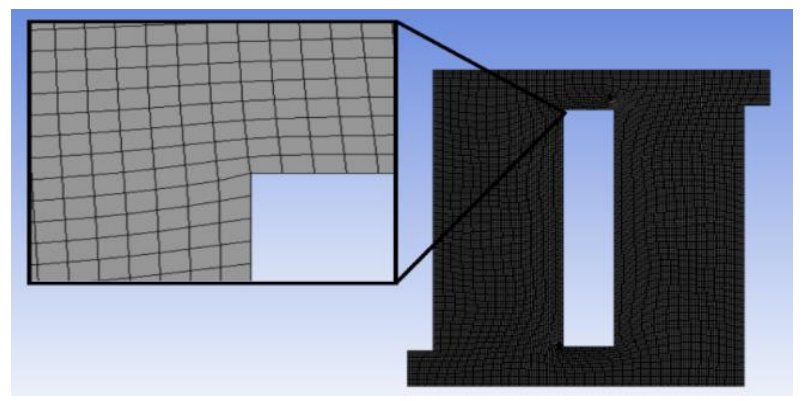

Figure 6. The computational domain for enclosure model. 


\section{RESULTS AND DISCUSSION EXPERIMENTAL RESULTS}

In this section, the results are presented and discussed to understand the influence of baffles on the heat transfer characteristics for natural and forced convection at the same inlet temperature and pressure. The baffles are placed at the heating block surface to form a single solid object inside the cavity. The tests are completed under varying operating parameters (heat flux, Reynolds number), and the block geometrical configurations include block without baffle (plain), block with baffles $\left(\mathrm{W}_{\mathrm{b}}=2.5,5,10 \mathrm{~cm}\right)$ and block with partially cut baffles $\left(\mathrm{W}_{\mathrm{b}}=5 \mathrm{~cm}\right)$. This section provides the correlations obtained from the experimental results at each heat flux.

\section{THE EFFECTS OF HEAT FLUX AND REYNOLDS NUMBER}

The effects of heat flux and Reynolds number on the average block surface temperature and Nusselt number are illustrated in Figures 7 and 8, respectively, for the plain case. The temperature decreases with the increase in the Reynolds number because of the increasing momentum of the air supplied to the enclosure that reduces the wall temperature. Turbulent intensity increases and causes heat dissipation. The Nusselt number increases with the increase in heat flux because of the increasing buoyancy driven flow inside the cavity. At the same inlet temperature and pressure with $\mathrm{Re}=16950$, the forced convection enhances the heat transfer than that of the natural convection by $59.4 \%$ because of the increase in the heat transfer coefficient.

Figures 9 and 10 present the variation of $\mathrm{Tw}_{\mathrm{a}}$ and $\mathrm{Nu}_{\mathrm{a}}$, respectively, under the variation of heat flux and Reynolds number to investigate the effects of adding baffles $\left(\mathrm{W}_{\mathrm{b}}=5 \mathrm{~cm}\right)$ to the heating block on the surface temperature and Nusselt number. The Nusselt number on the block with baffle is enhanced by approximately $7.3 \%$ at $\mathrm{Re}=5650$ compared with the plain case because of the development of turbulent circulation cells inside the cavity. Large and intense circulation cells lead to the increase in the heat transfer performance.

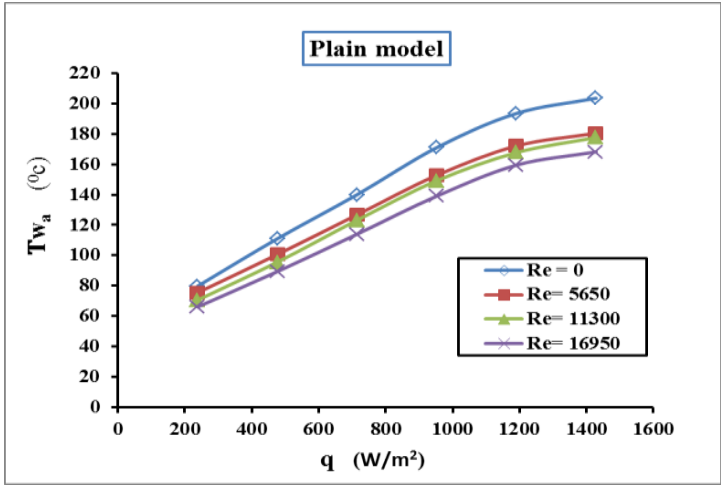

Figure 7. Effect of $(q)$ and $(\mathrm{Re})$ on $\left(\mathrm{Tw}_{\mathrm{a}}\right)$

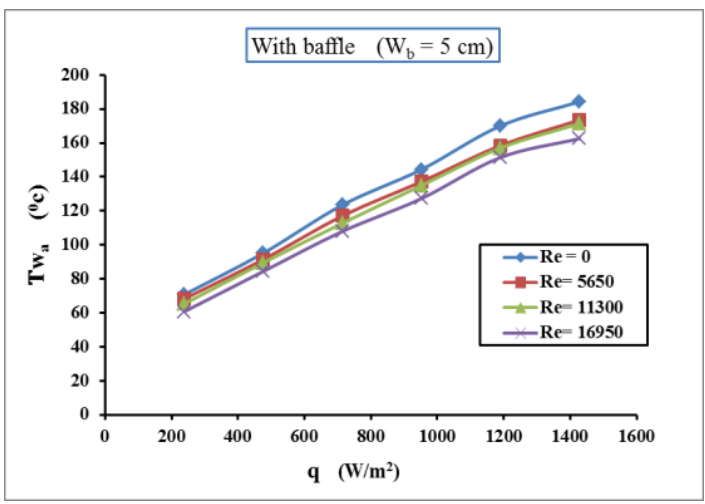

Figure 9. Effect of $(\mathrm{q})$ and $(\mathrm{Re})$ on $\left(\mathrm{Tw}_{\mathrm{a}}\right)$

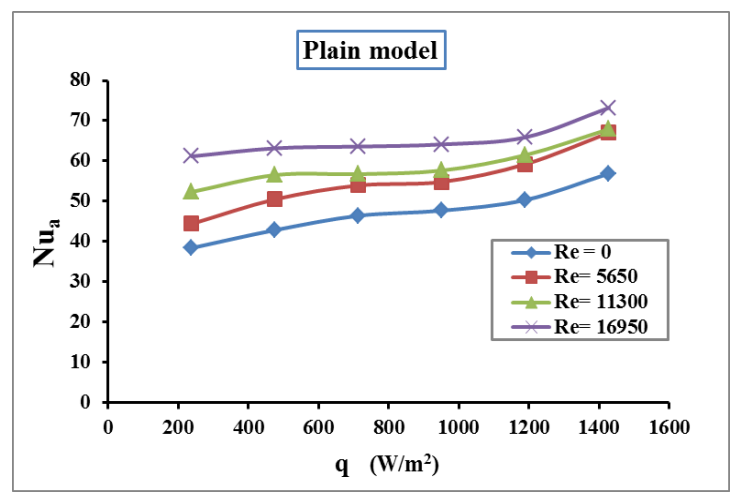

Figure 8. Effect of $(q)$ and $(\mathrm{Re})$ on $\left(\mathrm{Nu}_{\mathrm{a}}\right)$

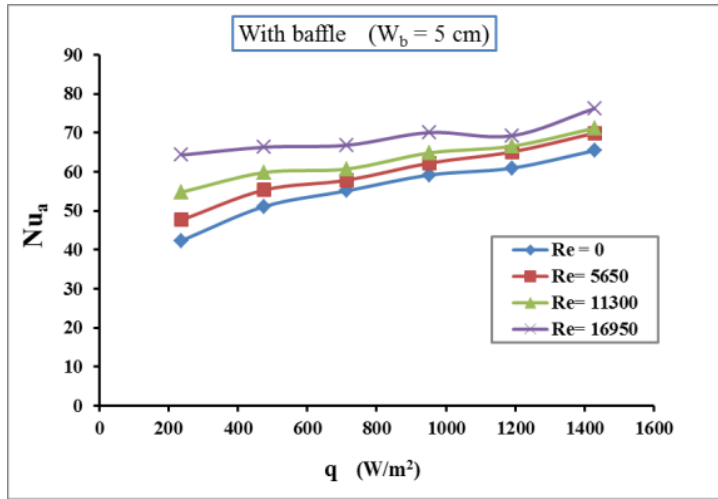

Figure 10. Effect of $(q)$ and $(\mathrm{Re})$ on $(\mathrm{Nua})\left(\mathrm{Nu}_{\mathrm{a}}\right)$ 
Similar results can be observed on the heated block with partially cut baffles, as shown in Figures 11 and 12 . The baffle shape has significant effect on surface temperature and Nusselt number, where the partially cut baffles have higher heat transfer performance compared with other baffles. The Nusselt number increases with the increase in the Reynolds number. Compared with natural convection, the percentage of $\mathrm{Nu}_{\mathrm{a}}$ at $\mathrm{Re}=16950$ increases by approximately $34.14 \%$.

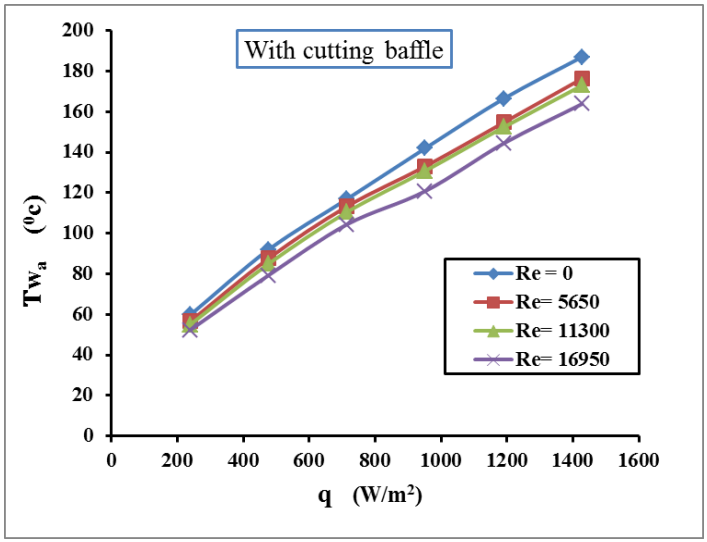

Figure 11. Effect of $(q)$ and $(\mathrm{Re})$ on $\left(\mathrm{Tw}_{\mathrm{a}}\right)$

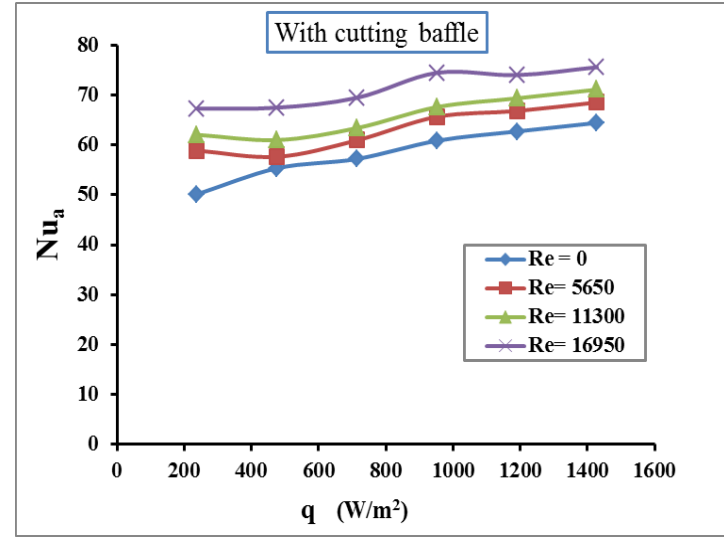

Figure 12. Effect of $(q)$ and $(\mathrm{Re})$ on $\left(\mathrm{Nu}_{\mathrm{a}}\right)$

The distributions of average block surface temperature at Reynolds number $(\operatorname{Re}=0,5650)$ with the variation of heat flux for all the cases are shown in Figure 13. The results of the plain case depict high wall temperature for natural and forced convection compared with other cases. At heat fluxes of $240-1200 \mathrm{w} / \mathrm{m}^{2}$, low values of Tw are achieved for the block with partially cut baffles. This condition is because of the effect of circulation cells generated by the baffle configuration. For the block with baffles, Tw decreases compared with the plain model, and a maximum decrease in Tw is obtained at $\mathrm{q}>1200 \mathrm{w} / \mathrm{m}^{2}$. The results show small influence in $\mathrm{Tw}$ with the change in the baffle width $5 \mathrm{~cm}$ to $10 \mathrm{~cm}$. For all the cases, the variation of average Nusselt number $(\mathrm{Nu})$ with heat flux $(\mathrm{q})$ at $\mathrm{Re}=0,5650$ is depicted in Figure (14). The block with partially cut baffles improves the Nu compared with the other models. The comparison of the partially cut baffles and the plain model shows a major increment of Nu by approximately $30 \%$ at $\mathrm{Re}=0$ with $\mathrm{q}=240 \mathrm{w} / \mathrm{m}^{2}$, and the $\mathrm{Nu}$ improves by approximately $32.6 \%$ at $\mathrm{Re}=5650$. This condition is typically attributed to the buoyancy and circulation cells around the baffle, especially at low Reynolds number, and the high recirculation flow inside the cavity at high Reynolds number.

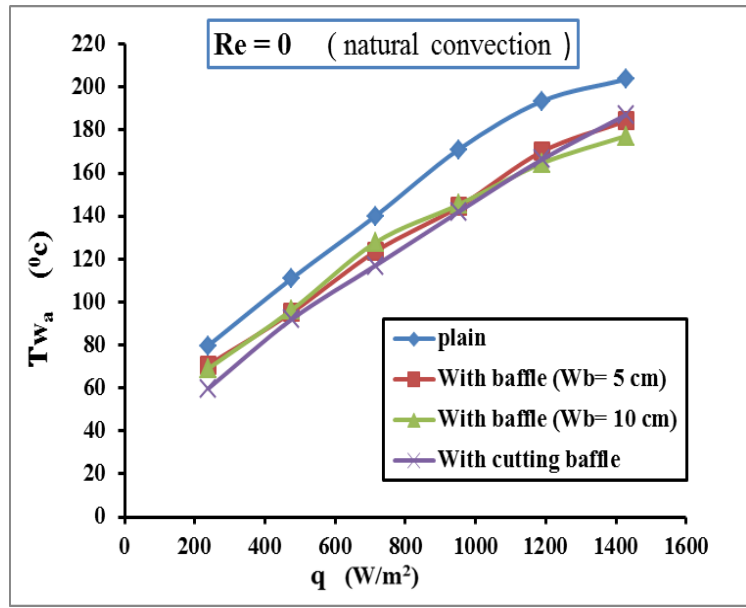

(a)

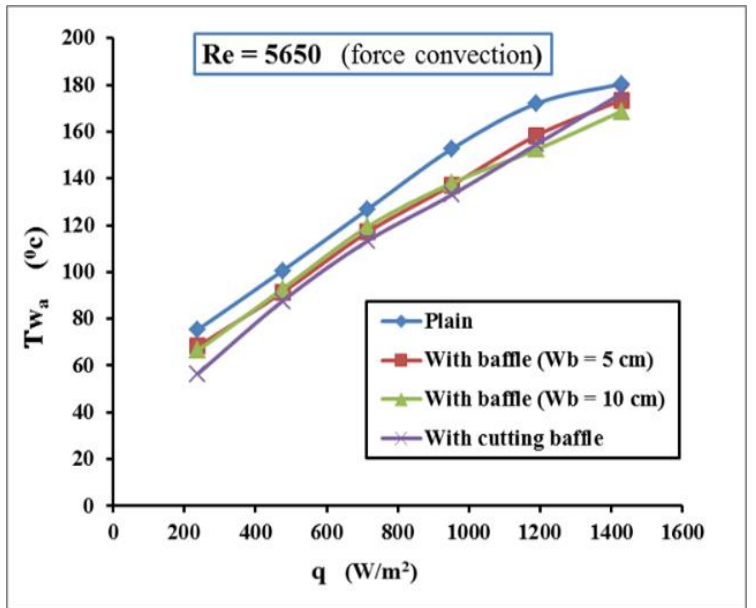

(b)

Figure 13. $\left(\mathrm{Tw}_{\mathrm{a}}\right)$ versus $(\mathrm{q})$ at $(\mathrm{Re}=0,5650)$ 


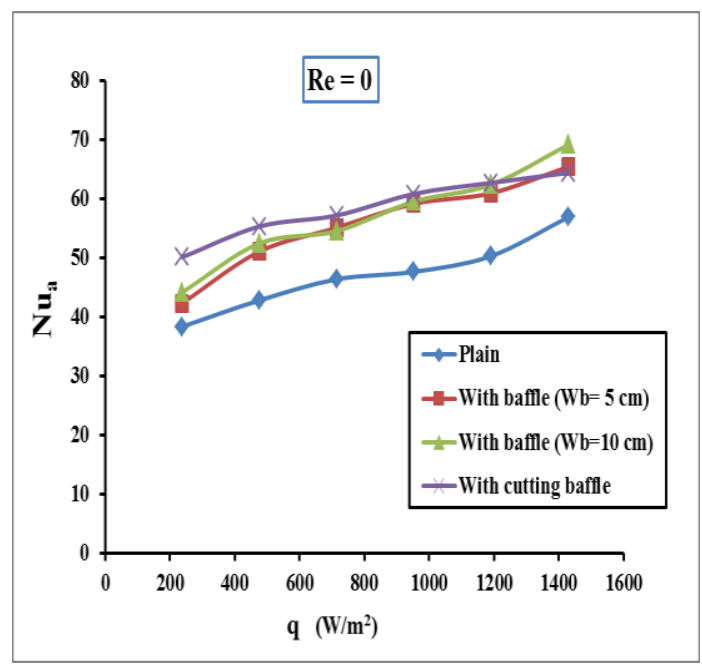

(a)

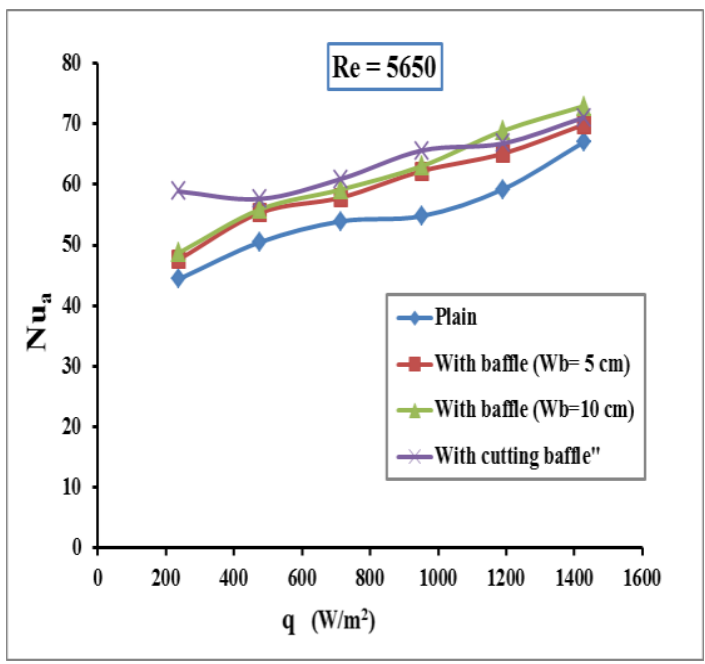

(b)

Figure 14. $\left(\mathrm{Nu}_{\mathrm{a}}\right)$ versus $(\mathrm{q})$ at $(\mathrm{Re}=0,5650)$

This work mainly aims to conduct many experiments for studying and comparing the natural and forced convection of all the models under the same operational conditions (inlet temperature, inlet pressure and heat flux). Table (3) shows the percentage increment of $\mathrm{Nu}_{\mathrm{a}}$ at forced convection compared with natural convection.

Table 3. Percentage increment of $\left(\mathrm{Nu}_{\mathrm{a}}\right)$

\begin{tabular}{|c|c|c|c|c|c|c|}
\hline \multirow{3}{*}{$\frac{\mathrm{q}}{\left(\mathrm{w} / \mathrm{m}^{2}\right)}$} & \multicolumn{6}{|c|}{ Increment percent $\%$} \\
\hline & \multicolumn{2}{|c|}{ Block without baffle } & \multicolumn{2}{|c|}{$\begin{array}{c}\text { Block with baffle } \\
\left(\mathrm{W}_{\mathrm{b}}=5 \mathrm{~cm}\right)\end{array}$} & \multicolumn{2}{|c|}{$\begin{array}{c}\text { Block with cutting } \\
\text { baffle }\end{array}$} \\
\hline & $\mathrm{Re}=5650$ & $\mathrm{Re}=16950$ & $\mathrm{Re}=5650$ & $\mathrm{Re}=16950$ & $\mathrm{Re}=5650$ & $\mathrm{Re}=16950$ \\
\hline 240 & 15.659 & 59.369 & 12.487 & 51.832 & 17.436 & 34.142 \\
\hline 475 & 17.852 & 47.469 & 8.311 & 29.817 & 4.149 & 21.907 \\
\hline 715 & 16.223 & 37.034 & 4.967 & 21.232 & 6.529 & 21.406 \\
\hline 950 & 14.974 & 34.521 & 5.176 & 18.400 & 7.871 & 22.351 \\
\hline 1190 & 17.709 & 30.959 & 6.827 & 13.608 & 6.512 & 17.977 \\
\hline 1425 & 17.821 & 28.730 & 6.838 & 16.521 & 10.343 & 17.295 \\
\hline
\end{tabular}

\section{THE EFFECTS OF THE WIDTH OF BAFFLE (Wb):}

The baffle width is a parameter that affects the heat transfer performance. Figure 15 shows the trend of $\mathrm{Nu}$ with $q$ at $\operatorname{Re}=0,5650$ to investigate the effects of $\mathrm{W}_{\mathrm{b}}$ on the $\mathrm{Nu}$ for the block with baffles. $\mathrm{The} \mathrm{Nu}$ at $\mathrm{Re}=0$ and $\mathrm{Re}=$ 5650 increases by approximately $6.7 \%$ and $3.6 \%$, respectively, by varying $\mathrm{W}_{\mathrm{b}}$ from $0 \mathrm{~cm}$ to $2.5 \mathrm{~cm}$. The $\mathrm{Nu}$ increases by $10.4 \%$ and $7.3 \%$ at $\mathrm{Re}=0$ and $\mathrm{Re}=5650$, respectively, when $\mathrm{W}_{\mathrm{b}}$ increases from $0 \mathrm{~cm}$ to $5 \mathrm{~cm}$. At $\mathrm{W}_{\mathrm{b}}>5 \mathrm{~cm}$, the data of the curves show small influence of $\mathrm{W}_{\mathrm{b}}$ on the average Nusselt number. Better enhancement is observed at $\mathrm{W}_{\mathrm{b}}$ $=5 \mathrm{~cm}$. As previously mentioned, $\mathrm{Nu}_{\mathrm{a}}$ enhances because of the circulation cells induced by the baffles, which increase the heat transfer between the heating block and air flow inside the cavity. 


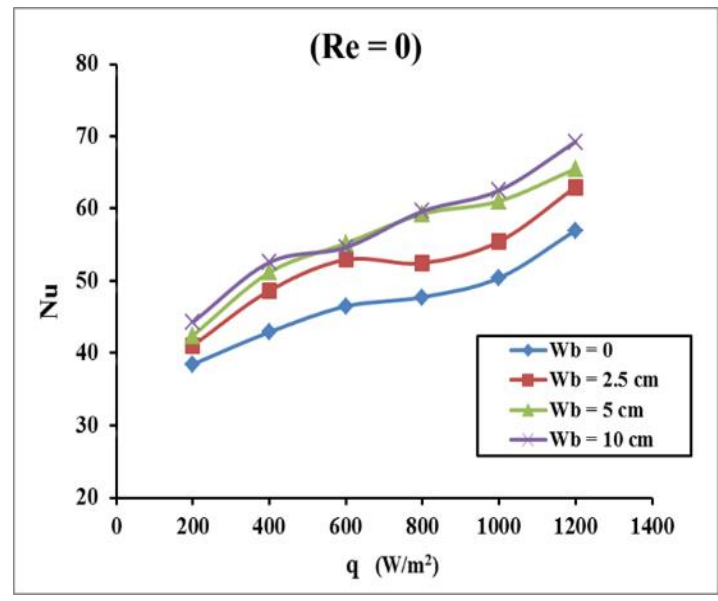

(a)

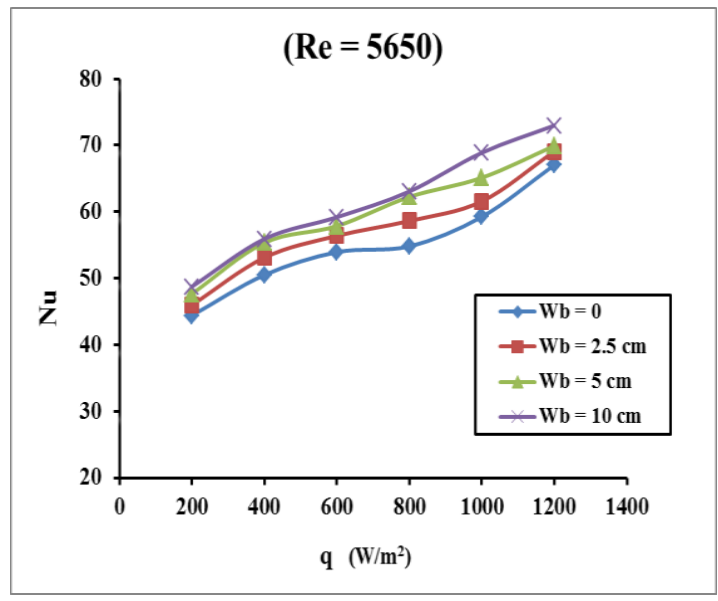

(b)

Figure 15. $\left(\mathrm{Nu}_{\mathrm{a}}\right)$ versus $(\mathrm{q})$ at $(\mathrm{Re}=0,5650)$ for block with baffle case

\section{VALIDATION OF NUMERICAL MODEL}

The Nusselt number is used as the main criterion to compare between the experimental and numerical results for the plain model to verify the present experimental work. The comparison is presented in Figure 16 for two Reynolds numbers. The data show that the numerical simulation and experimental measurement results are consistent with each other. The differences can be attributed to the heat loss from the cavity to the environment although the enclosure is well-insulated.

The results show that the experimental data are smaller than the numerical data, and this condition may be because of the difference in the values of air thermal conductivity and heat transfer coefficient. The thermal conductivity is assumed constant in the numerical analysis but it increases with the increase in temperature during the experiment. The maximum deviation between the experimental and numerical values is approximately $12.5 \%$.

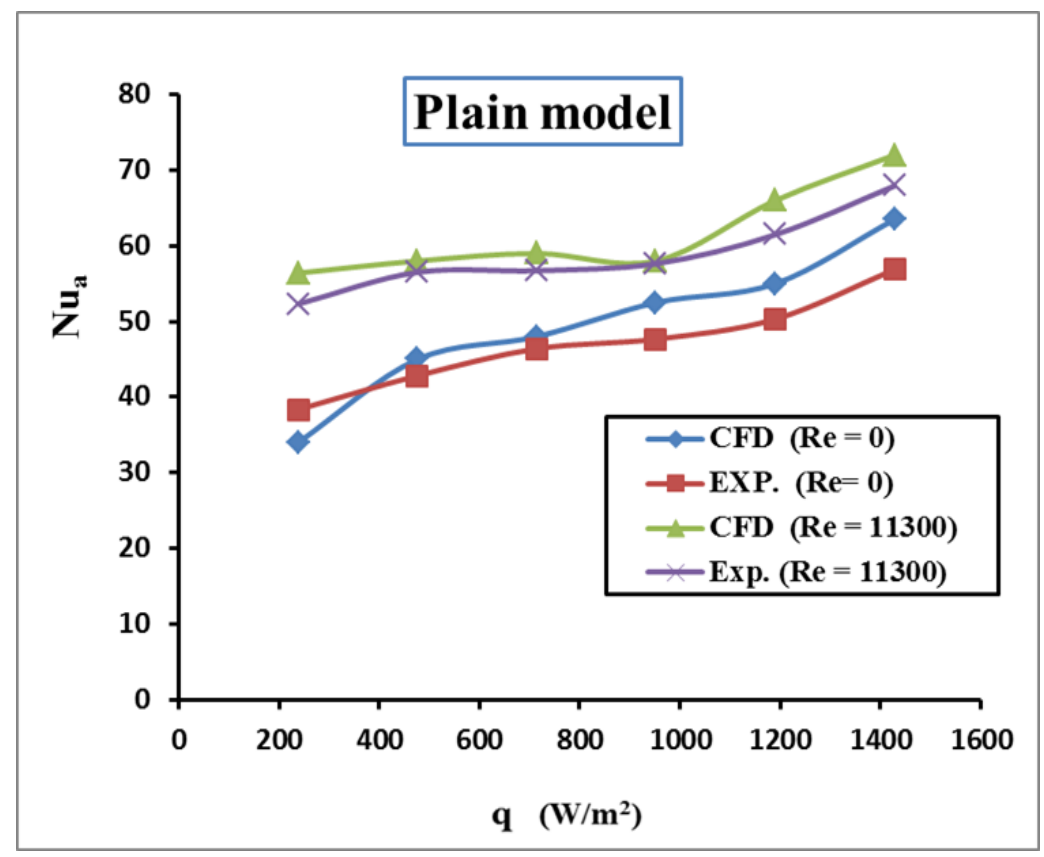

Figure 16. Comparison of the results (Num. and Exp.) 


\section{NUMERICAL RESULTS}

In this study, the numerical simulation results are obtained for air flow with PR of 0.72 . The parameters of governing physical equations are the Nusselt and Reynolds numbers. All these values vary over wide ranges to study the effects on the fluid flow and heat transfer inside the cavity. The simulation results are presented as isotherm contours and stream functions. The variation of inlet velocity, applied heat flux and the width of attached baffles are studied to analyse the effects of these parameters upon the heat transfer and fluid flow inside the cavity. The isotherm and stream function contours for various $\mathrm{Re}=0,5650$ and 11300 with uniform heating along the heated block wall are plotted in Figure 17. The fluid moves along the heated vertical block wall and rises up, forming a cell with counterclockwise rotation inside the cavity because of the interaction between the hot surfaces of the block with the external cold inlet air that flows from the bottom of the cavity over the heated wall. The hot region rises up with the increase in the inlet velocity, and different temperatures are found between the regions around the vertical block because of the increase in the cooling.

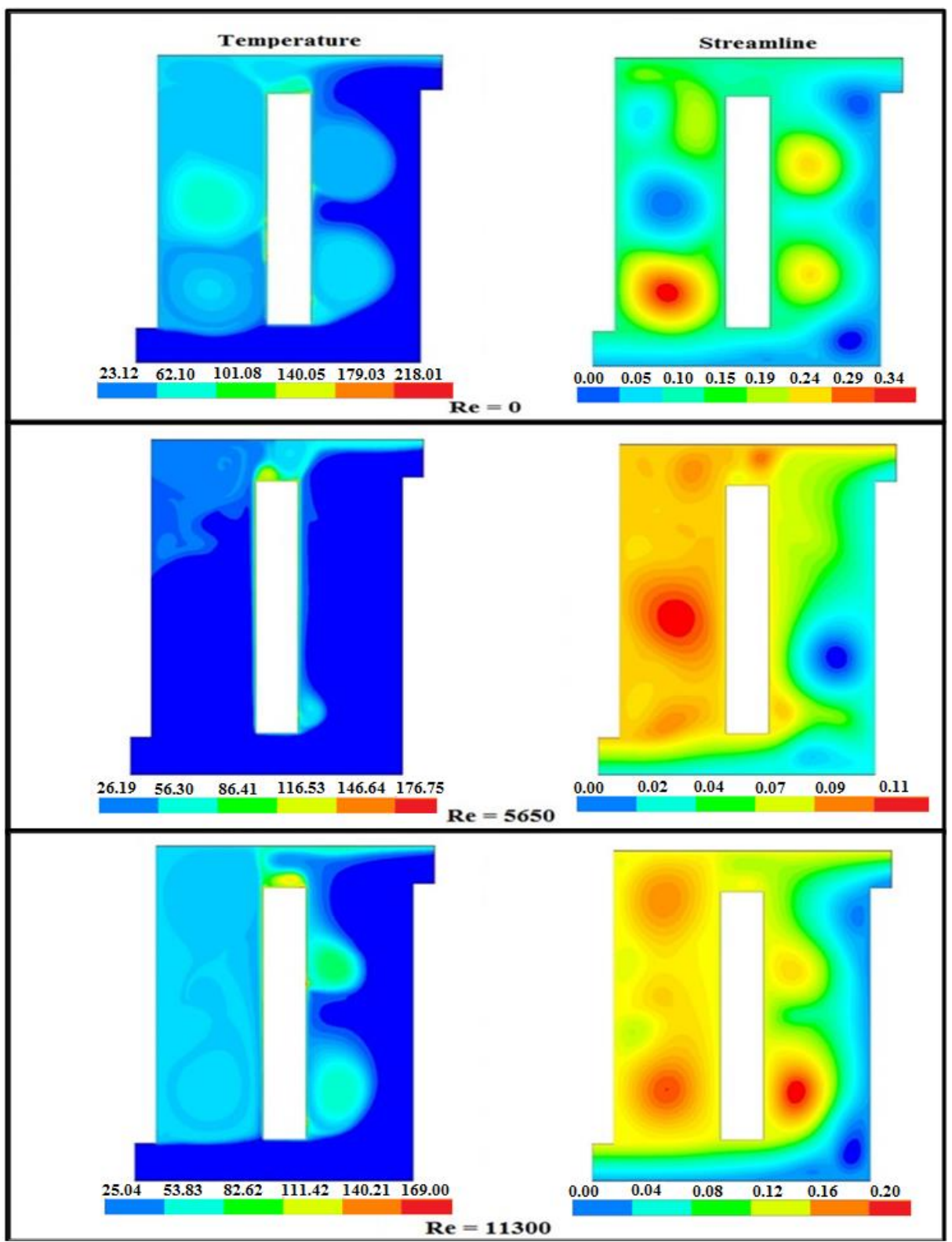

Figure 17. Effect of Reynolds number on the temperature and streamline contours at $\left(\mathrm{q}=1190 \mathrm{~W} / \mathrm{m}^{2}\right) \quad$ (plain model $)$ 
Figure 18 presents the effect of increasing the applied heat flux on the isotherm and stream function contours inside the cavity. The increase in heat flux increases the temperatures inside the cavity, the buoyancy force cell around the cavity, and the stream function cell intensity in the left side of the cavity that rises to the top region of the cavity.

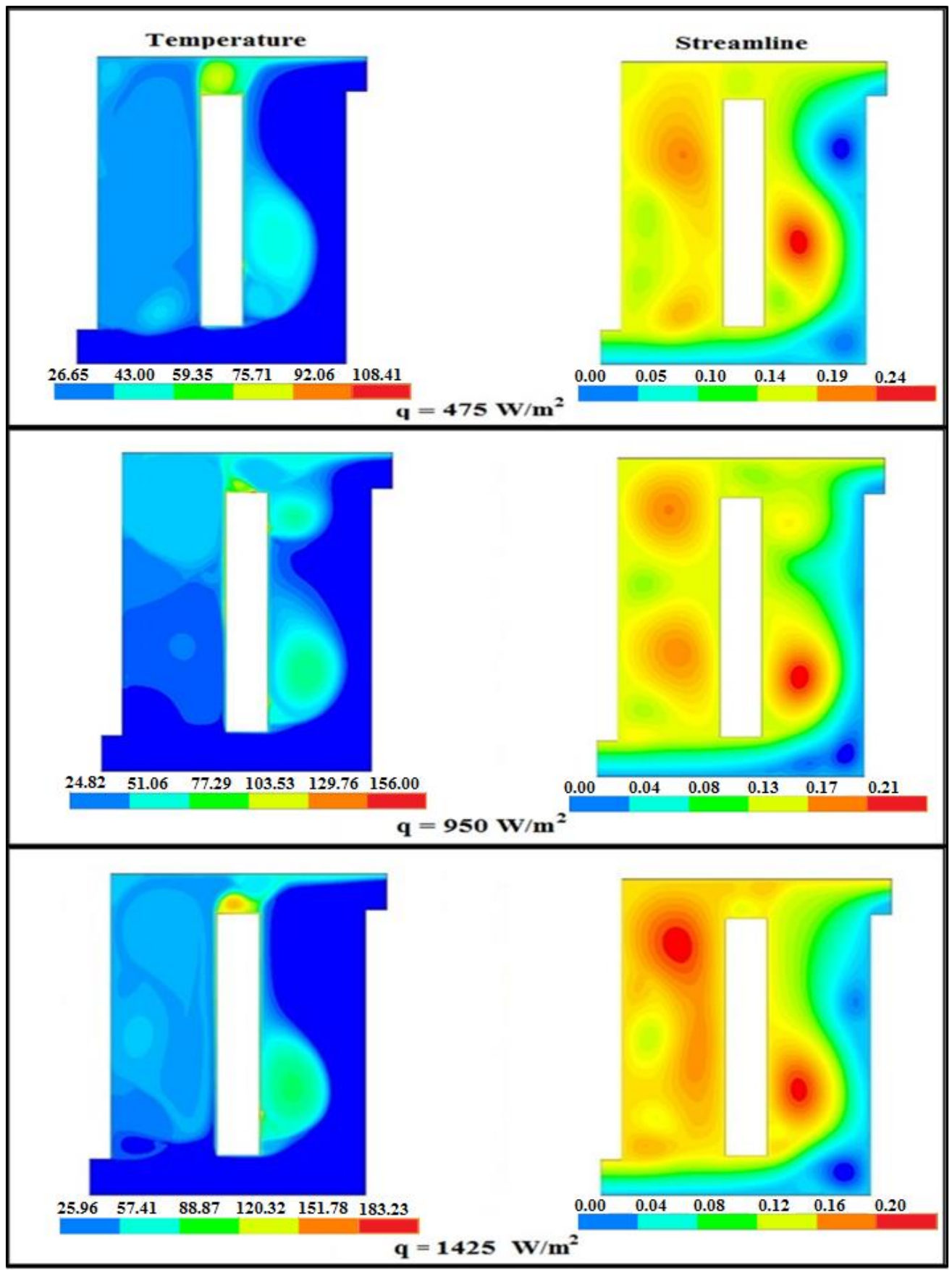

Figure 18. Effect of applied heat flux on the temperature and streamline contours at $(\operatorname{Re}=$ 5650) (plain model)

Figures 19 and 20 present the isotherm and stream function contours inside the cavity by-comparing the three cases with attached baffles and different widths $\left(\mathrm{W}_{\mathrm{b}}=5\right.$ and $\left.10 \mathrm{~cm}\right)$. The results show that the increase in baffle width increases the heat transfer in the two sides of the heated blocks and the temperatures of regions because of the increase 
in the turbulent circulation cells in the flow direction of the inlet air flow. Increasing the width of the baffles increases the number of cells in the left side of the heated block.

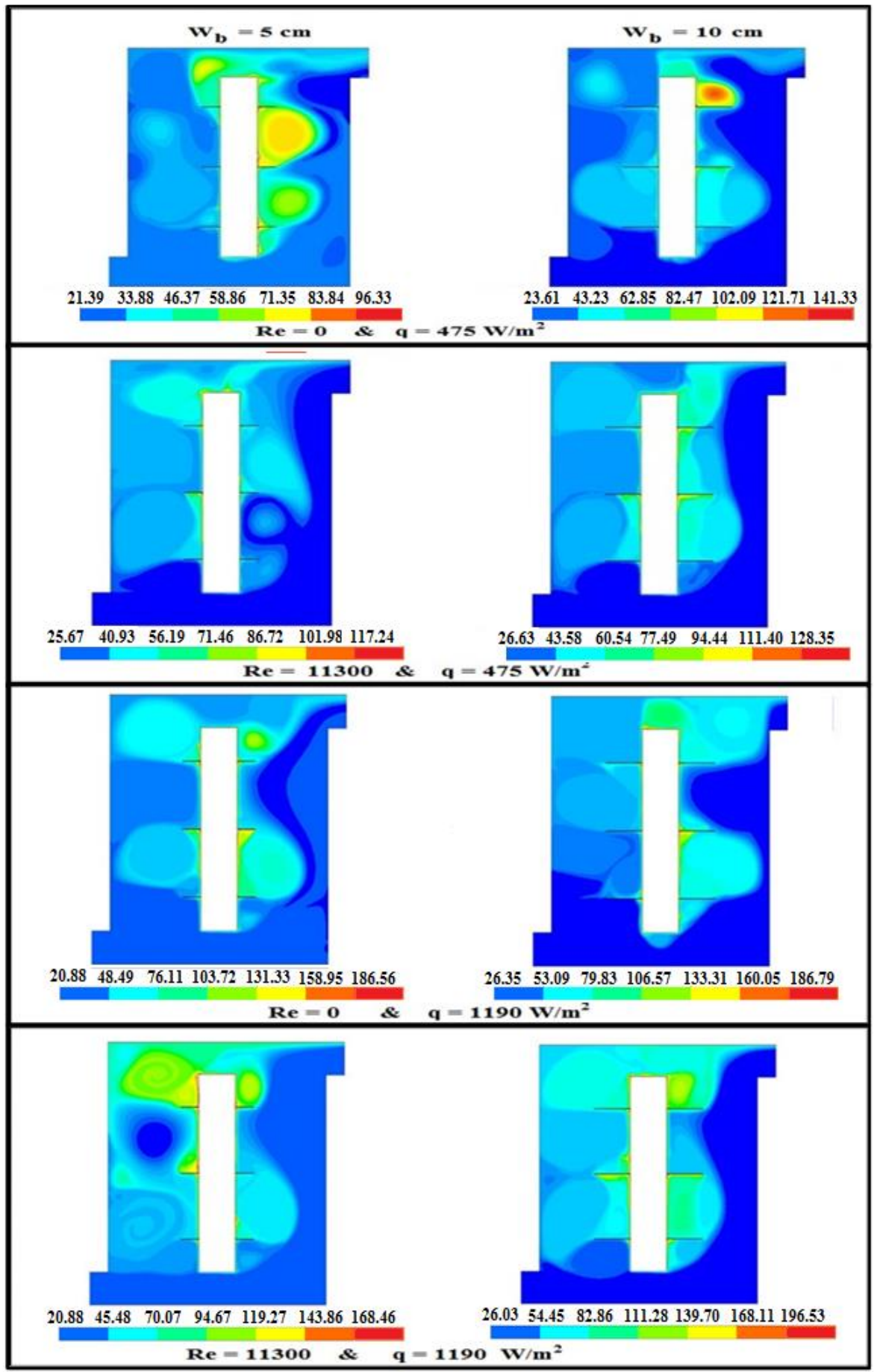

Figure 19. Effect of Reynolds number, applied heat flux and baffle width on the temperature contours (for baffle model). 


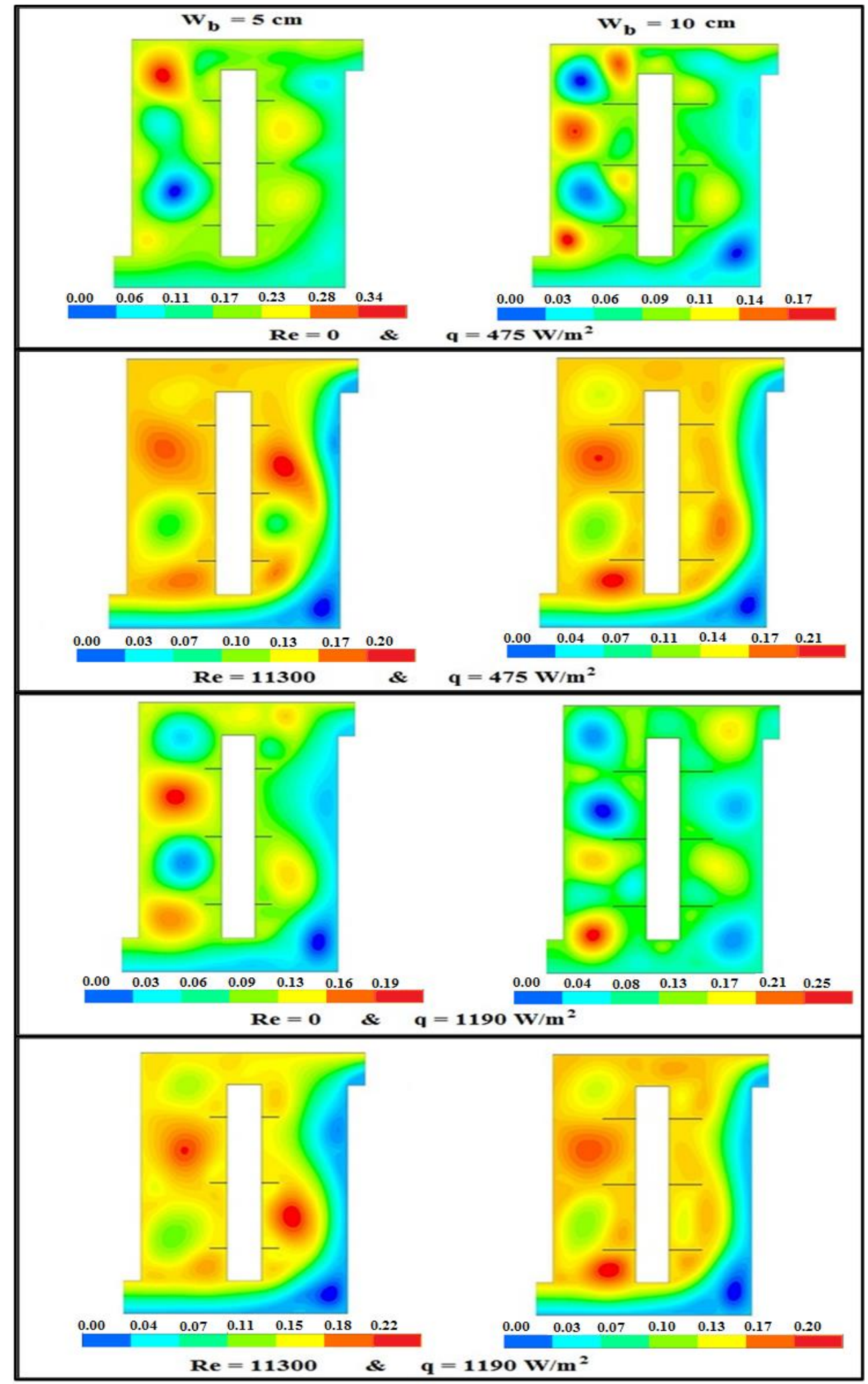

Figure 20. Effect of Reynolds number, applied heat flux and baffle width on the streamline contours. (Baffle model) 


\section{HEAT TRANSFER CORRELATIONS}

A conventional non-dimensional method is used to correlate the average Nusselt number of the block with baffle at forced convection state by introducing non-dimensional parameters, including $R e, W_{b} / W_{e}$ and $P R$ as follows:

$$
\mathrm{Nu}_{\mathrm{a}}=\mathrm{c} \operatorname{Re}^{\mathrm{n}}\left(\mathrm{W}_{\mathrm{b}} / \mathrm{W}_{\mathrm{e}}\right)^{\mathrm{m}} \operatorname{Pr}^{0.33}
$$

Where $c, n$ and $m$ are constants determined by experiments.

The experimental data of the block with baffle model at different heat fluxes are obtained, and the least square mathematical technique is performed to achieve the important correlations. At each heat flux, the summary of correlations, maximum and average deviations (error) between the correlated and the experimental values are listed in Table (4) at the Reynolds number from 5650 to 16950 and baffle width $\left(\mathrm{W}_{\mathrm{b}}\right)$ from $2.5 \mathrm{~cm}$ to $10 \mathrm{~cm}$ with $\mathrm{W}_{\mathrm{e}}=60 \mathrm{~cm}$.

Table 4. The empirical correlations

\begin{tabular}{|c|c|c|c|}
\hline $\begin{array}{c}\text { Heat flux } \\
\left(\mathrm{W} / \mathrm{m}^{2}\right)\end{array}$ & Empirical Correlation & $\begin{array}{c}\text { Max. error } \\
(\%)\end{array}$ & $\begin{array}{c}\text { Average error } \\
(\%)\end{array}$ \\
\hline 240 & $\mathrm{Nu}_{\mathrm{av}}=5.783 \mathrm{Re}^{0.26}\left(\mathrm{~W}_{\mathrm{b}} / \mathrm{W}_{\mathrm{e}}\right)^{0.023} \operatorname{Pr}^{0.33}$ & 6.70 & 2.75 \\
\hline 475 & $\mathrm{Nu}_{\mathrm{av}}=18.695 \mathrm{Re}^{0.143}\left(\mathrm{~W}_{\mathrm{b}} / \mathrm{W}_{\mathrm{e}}\right)^{0.025} \operatorname{Pr}^{0.33}$ & 4.99 & 1.78 \\
\hline 715 & $\mathrm{Nu}_{\mathrm{av}}=25.792 \mathrm{Re}^{0.11}\left(\mathrm{~W}_{\mathrm{b}} / \mathrm{W}_{\mathrm{e}}\right)^{0.019} \operatorname{Pr}^{0.33}$ & 4.76 & 2.20 \\
\hline 950 & $\mathrm{Nu}_{\mathrm{av}}=27.910 \mathrm{Re}^{0.111}\left(\mathrm{~W}_{\mathrm{b}} / \mathrm{W}_{\mathrm{e}}\right)^{0.032} \operatorname{Pr}^{0.33}$ & 3.14 & 1.91 \\
\hline 1190 & $\mathrm{Nu}_{\mathrm{av}}=48.281 \mathrm{Re}^{0.062}\left(\mathrm{~W}_{\mathrm{b}} / \mathrm{W}_{\mathrm{e}}\right)^{0.054} \operatorname{Pr}^{0.33}$ & 2.04 & 1.16 \\
\hline 1425 & $\mathrm{Nu}_{\mathrm{av}}=50.071 \mathrm{Re}^{0.066}\left(\mathrm{~W}_{\mathrm{b}} / \mathrm{W}_{\mathrm{e}}\right)^{0.053} \operatorname{Pr}^{0.33}$ & 1.95 & 1.11 \\
\hline
\end{tabular}

\section{CONCLUSION}

In the present study, experimental and numerical analyses are conducted to investigate the enhancement of heat transfer for natural and forced convection inside the enclosure containing heating block with and without baffles. The conclusions are provided as follows:

1. The baffles distribute the flow inside the cavity and create many circulation cells that enhance the heat transfer.

2. Increasing the baffle width from $5 \mathrm{~cm}$ to $10 \mathrm{~cm}$ has no measurable effect on heat transfer improvement.

3. In the forced convection, the enhancement in $\mathrm{Nu}$ is approximately $36 \%$ compared with the natural convection at $\operatorname{Re}=11300$ and $q=240 \mathrm{w} / \mathrm{m}^{2}$ for the plain case.

4. Partially cut baffles provides better improvement in $\mathrm{Nu}$ by approximately $30 \%$ compared with the plain case at $\operatorname{Re}=0$ and $q=240 \mathrm{w} / \mathrm{m}^{2}$, whereas the Nu improves by approximately $32.6 \%$ at $\operatorname{Re}=5650$.

5. The baffle cases have an evident effect in reducing the block surface temperature by approximately $11 \%$ compared with the plain case at $\operatorname{Re}=0$ and $q=240 \mathrm{w} / \mathrm{m}^{2}$.

6. The mixed convection results can be observed at the turbulent flow $(\operatorname{Re} \approx 5000)$. At high heat flux value $(q>$ $900 \mathrm{~W} / \mathrm{m}^{2}$ ), the combined effects of natural and forced convection heat transfer are observed, whereas at low values of $q$, the forced convection is dominant.

7. Although the forced convection enhances the heat transfer, this improvement is at the expense of cost or applicability. Therefore, natural convection is preferred to improve the heat transfer in cooling the devices.

8. This work mainly aims to conduct many experiments for studying and comparing the natural and forced convection of all the models under the same operational conditions (inlet temperature, inlet pressure and heat flux). 
Journal of Thermal Engineering, Research Article, Vol. 7, No. 3, pp. 367-386, March, 2021

\section{NOMENCLATURE}

A Heated surface area, $\mathrm{m}^{2}$

Dh Hydraulic diameter, $m$

g Gravitational acceleration, $\mathrm{m} / \mathrm{s}^{2}$

$H \quad$ Height, $\mathrm{m}$

I Electric current, Amp.

$h \quad$ Heat transfer coefficient, $\mathrm{W} / \mathrm{m}^{2} . \mathrm{k}$

Kair Thermal conductivity of the air, W/m.K

$L \quad$ Length, $\mathrm{m}$

$\mathrm{Nu} \quad$ Nusselt number

$P \quad$ Power supply, (watt)

$V \quad$ Voltage, Volt

W Width, $\mathrm{m}$

$\operatorname{Pr} \quad$ Prandtle number

$P R \quad$ Pitch ratio, $\mathrm{m}$

$Q \quad$ Heat transfer rate, Watt

$q \quad$ Heat flux, $\mathrm{W} / \mathrm{m}^{2}$

Re Reynolds number

$\mathrm{Ra} \quad$ Rayleigh number

$T \quad$ Temperature, ${ }^{\circ} \mathrm{C}$

TF $\quad$ Film temperature, ${ }^{\circ} \mathrm{C}$

Tw Wall temperature, ${ }^{\circ} \mathrm{C}$

$T \infty \quad$ Flow temperature, ${ }^{\circ} \mathrm{C}$

$U \quad$ Velocity of flow, $\mathrm{m} / \mathrm{s}$

$N \quad$ No. of temperature measurements

\section{Greek symbols}

$\begin{array}{cl}\rho & \text { Density of the air, } \mathrm{kg} / \mathrm{m}^{3} \\ \mu & \text { Dynamic viscosity of air, } \mathrm{kg} / \mathrm{m} . \mathrm{s} \\ v & \text { Kinematic viscosity of air, } \mathrm{m}^{2} / \mathrm{s} \\ \beta & \text { Coefficient of volume expansion, } 1 / \mathrm{K}\end{array}$

$\begin{array}{ll}\text { Subscript } & \\ a & \text { Average } \\ B & \text { Heating block } \\ b & \text { Baffle } \\ e & \text { Enclosure } \\ w & \text { Wall }\end{array}$

\section{REFERENCES}

[1] Yang, L., Du, K. A comprehensive review on the natural, forced, and mixed convection of non-Newtonian fluids (nanofluids) inside different cavities. J Therm Anal and Calorim. 2020, 140, 2033-2054. DOI: https://doi.org/10.1007/s10973-019-08987-y.

[2] Abdelouahed T. A four variable trigonometric integral plate theory for hygro-thermo-mechanical bending analysis of AFG ceramic-metal plates resting on a two-parameter elastic foundation. Steel and Composite Structures. 2020,34(4), 511-524, DOI: http://dx.doi.org/10.12989/scs.2020.34.4.511.

[3] Hakima M. Investigation on hygro-thermal vibration of P-FG and symmetric S-FG nanobeam using integral Timoshenko beam theory. Advances in Nano Research. 2020; 8(4), 293-305, DOI: https://doi.org/10.12989/anr.2020.8.4.293.

[4] Burlayenko V. Modelling functionally graded materials in heat transfer and thermal stress analysis by means of graded finite elements. Applied Mathematical Modelling. 2017; 45, 422-438, DOI: https://doi.org/10.1016/j.apm.2017.01.005.

[5] Safaa A., Salah H., Kadhum A. Jehhef. Numerical Modelling of Fluid Flow and Heat Transfer of (TiO2Water) Nanofluids in Wavy duct. IOP Conf. Ser.: Mater. Sci. Engineering 2020; Vol.881, 012162. DOI: $10.1088 / 1757-899 \mathrm{X} / 881 / 1 / 012162$. 
[6] Laguerre O., Ben S., Flick D. Experimental study of heat transfer by natural convection in a closed cavity: application in a domestic refrigerator. Elsevier, journal of food engineering. 2005; 70, 523-537. DOI: 10.1016/j.jfoodeng.2004.10.007.

[7] Himsar A., Kouki K., Mashasi D.,Takeo S.,Hiroshi T. , Jun S. Laminar natural convection heat transfer in an air filled square cavity with two insulated baffles attached to its horizontal walls. Thermal science \& engineering. 2006; 14(3), 35-46. DOI: 10.11368/tse.14.35.

[8] Nabeel M., Selah M. Numerical study of laminar forced convection heat transfer in a horizontal channel with isothermal baffle. F.T.E. Scientific international conference. 2010 Apr 12-14; Al-Najaf al-Ashraf, Iraq.

[9] Withada J., Supattarachai S., Pongjet P. Numerical study of laminar heat transfer in baffled square channel with various pitches. Elsevier, Energy procedia. 2011; 9, 630- 642.

[10] Ahmed M., Mostafa N., Mustapha E. Convective mixed heat transfer in a square cavity with heated rectangular blocks and submitted to a vertical forced flow. FDMP. 2011; 7(1), 97-110. DOI: 10.3970/fdmp.2011.007.097.

[11] Asif M., Hossain M., Hossain K. Heat transfer in a rectangular enclosure with baffles. ARPN Journal of engineering and applied science. 2011; 6(4), 29-41.

[12] Ahammad M., Rahman M., Rahman L. Mixed convection flow and heat transfer behavior inside a vented enclosure in the presence of heat generating obstacle. International journal of innovation and applied studies. 2013; 3(4), 967-978.

[13] Ragui K., Benkahla Y., Labsi N., Boutra A. Natural heat transfer convection in a square cavity including a square heater. Proceedings of the $21^{\text {st }}$ French Congress of Mechanics; 2013 Aug 26 to 30, Bordeaux, France.

[14] Armando P., Hinojosa J. Numerical and experimental study of heat transfer in a tall vertical closed cavity, Heat and mass transfer. 2013; 49, 933-945. DOI: 10.1007/s00231-013-1136-9.

[15] Barka M., Hicham R., El alami S., Mustapha A., Mostafa N. Mixed convection and heat transfer in a "T" form cavity: The effect of inclination. FDMP. 2014; 10(3), 395-415. DOI: 0.3970/fdmp.2014.010.395.

[16] Louhibi M., Salhi N., Bouali H., Amghar K. Numerical analysis of heat transfer in a channel wit inclined baffles. International journal of engineering and science. 2014; 4(8), 12-23.

[17] Yasin V., Filiz O. Effect of inclined thick fin on natural convection in a cavity heated from bottom. Progress in computational fluid dynamics. 2015; 15(1). DOI: 10.1504/PCFD.2015.067324.

[18] Antonio C. Assessment of the performances of a heat exchanger in a light helicopter. Advances in Aircraft and Spacecraft Science. 2015; 2(4), 469-482. DOI: 10.12989/aas.2015.2.4.469.

[19] Raj K., Ranchan C., Muneesh S., Ashutosh S., Anil K. Experimental investigation of effect of flow attack angle on thermo hydraulic performance of air flow in a rectangular channel with discrete V-pattern baffle on the heated plate. Advances in mech engineering. 2016; 8(5), 1-12. DOI: 10.1177/1687814016641056.

[20] Ammart B., Withada J. Numerical investigation on turbulent forced convection and heat transfer characteristics in a square channed with discrete combined V- baffle and V- orifice. Elsevier, Case Studies in Thermal Engineering. 2016; 8, 226- 235. DOI: 10.1016/j.csite.2016.07.003.

[21] Ahmed E., Christophe B., Steve J., Jesper C., Humberto M., Hassan K. Investigation of baffle configuration effect on the performance of exhaust mufflers. Elsevier, Case Studies in Thermal Eng. 2017; 10, 86- 94. DOI: 10.1016/j.csite.2017.03.006.

[22] Amghar K., Louhibi M., Salhi N., Salhi M. Numerical simulation of forced convection turbulent in a channel with transverse baffles. Journal of materials and environmental science, 2017; 8(4), 1417-1427.

[23] Eva T., Jan T., Matej S. Numerical and experimental study of conjugate heat transfer in a horizontal air cavity. building simulation journal. 2018; 11, 339-346. DOI: 10.1007/s12273-017-0403-y.

[24] Adis Z., Darren L. Influence of fin partitioning of a Rayeigh-Bénard cavity at low Rayleigh numbers. Advances in Aircraft and Spacecraft Science. 2018; 5(4), 411-430. DOI: 10.12989/aas.2018.5.4.411.

[25] Sannad M., Abourida B., Belarche L., Doghmi H., Ouzaouit M. Effect of the heating block position on natural convection in a three - dimensional cavity filled with nanofluids. Journal of applied fluid mechanics. 2019; 12(1), 281-291. DOI: 10.29252/JAFM.75.253.29026.

[26] Assim H., Amer M., Salah H. Heat transfer and flow performance of impingement and impingement/effusion cooling systems. Engineering and Technology Journal. 2015; 33(6), 1518-1536.

[27] Nabeel S. Investigation of heat transfer enhancement with nanofluid and twisted tape inserts in a circular tube. Ph.D. thesis. University of Technology, Iraq; 2014.

[28] Kline S., Mcclintock F. Describing uncertainties in single sample experimental. Mechanical Engineering, 1953; 75, 3-8.

[29] Holman J. Heat transfer. Ninth Edition, New York, McGraw-Hill Companies, 2008.

[30] Roy J., Boulard T., Bailly Y. An experimental study of natural convection in a heated greenhouse. Proceedings of the French Thermal Congress, SFT. 2000 May 15-17, Lyon, France. 
Journal of Thermal Engineering, Research Article, Vol. 7, No. 3, pp. 367-386, March, 2021

[31] Román N., Anabel L., Jean F., Octavio G., Isaac P. Computational fluid dynamics analysis of heat transfer in a greenhouse solar dryer "chapel- type" coupled to an air solar heating system. Energy Science \& Engineering. 2019; 7(4), 1123-1139. DOI: 10.1002/ese3.333.

[32] Markatos N. C., Pericleous K. A. Laminar and turbulent natural convection in an enclosed cavity. International. J. Heat Mass Transfer. 1984; 27(5), 775-772. DOI: 10.1016/0017-9310(84)90145-5.

[33] Zhang Y., Xin W., Yibo M., Baoyan X., Dong S. Simulation and experiments of active greenhouse heating system. 2019; 25(2), 53-59. DOI: 10.5755/j01.eie.25.2.23205.

[34] Gorobets V., Trokhaniak V. The numerical simulation of heat and mass transfer processes in tunneling air ventilation system in poultry houses. Inmateh agricultural engineering, 2018; 55(2), 87-96.

[35] Davis G. Natural convection of air in a square cavity, a bench mark numerical solution. International. J. for Numerical. Methods of Fluids. 1983; 3(3), 249-264. DOI: 10.1002/fld.1650030305. 